To my friend in echocardiography

I bet you think everything I write is just amusing and, because you're not an American, you are insulated from our various crazy goings on. This year you wanted to know about our recent presidential election, thinking you felt safe. Not so, for we re-elected Bill Clinton to carry us into the millennium. Two years ago we thought he was politically disappearing. "The Incredible Shrinking President," heralded the cover of Time magazine.

Hillary (er, Hillary Rodham Clinton) was a dismal failure in her attempt to control changes in the health care system in this country. You probably think that pleased me. You also probably think I still have a problem with the President putting a lawyer in charge of making medical policy. It didn't matter that our health care system had been in economic transformation for more than a decade. As you know, it didn't go well for her, or us physicians. She frightened the medical community with heavy handed committees and administrative panels that accelerated mediocrity in American medicine, we call it managed care.

In November I herniated a lumbar disc. Sure I reclined on a heating pad and limped about for over three months, then, I finally got an MRI. "Wow, you should have had surgery," indicated the consultant surgeon. Talk about a victim of managed care!

Well, the health care issue didn't make a positive impact on Mr Clinton's image, so our man in Washington tried to make his mark in foreign affairs using Somalia and Haiti. Somalia was a bust, but Haiti presented a nice opportunity for political redemption. Why not make the world a safer place by using American troops wherever and whenever needed? It's our moral imperative after all. Anyway, a well timed armed invasion has always given a President a good boost in the popularity polls. Haiti was a place where a group of thugs that terrorised the population needed to be taught a lesson. Certainly Haiti was probably high on everyone else's list of mortal enemies. After nearly a fortnight of languishing in the harbour of Port-au-Prince, we staged a successful invasion followed by pacification. We put a billion dollars into it each year. For a paltry $\$ 65$ million we hired and trained a specialised police force that has turned into a group of thugs that terrorises the population. I guess the difference is they now have nice uniforms.

Congress was controlled by the opposition party and the government was in a stalemate. Very little was happening domestically. Various FOB (Friends of Bill) were being indicted and convicted of a variety of crimes, secret FBI files on members of the opposition party were being improperly called to the White House, subpoenaed documents (in other investigations) were disappearing from the White House private quarters. Nobody really cared about health care any more. $\mathrm{Mr}$ Clinton's popularity ratings could only be compared to John Major's.

\section{A metamorphosis}

But then there were changes. In fact, there was a metamorphosis like none seen on this continent in recent decades. If he was personally unpopular and had political views that were out of touch with the country, simply change views, he reasoned. And he did! He hired a consultant to develop a programme on "family values", a clear move towards the cause of the other party. As you know, the consultant later resigned when his dalliances were revealed in a tabloid (the man is alleged to actually have let the lady listen in to his conversations with the President).

Never mind the resignation, the whole thing worked and Bill was re-elected using a recreated imaging in the likeness of his opposition. The Republicans are happy because $\mathrm{Mr}$ Clinton ran for election on their issues. I don't know what that says for Bob Dole, but just the other day he said he was now enjoying walking the dog every morning and afternoon. I don't know why he is so calm, he's in his 70 s and will soon probably need Medicare.

Every January our President must deliver an address to the nation on the State of the Union (aka the USA). This year, Mr Clinton announced his talk would be over an hour long as he stretched the bounds of common sense. Just as he was about to make his strong points about the merits of adding roughage to one's diet and the dangers of tooth decay, the jury in the OJ civil trial announced its verdict.

I don't know what was more significant in this cultural meltdown for America, but I know who won the TV ratings. Some networks switched to the exterior of the courtroom in Santa Monica; the others ran news banners on the lower third of the screen. The President was finally placed in a very strange perspective by $\mathrm{OJ}$ and a pair of Bruno Magli shoes. I should add, he never mentioned echocardiography once.

I don't know what happened to Hillary Rodham Clinton through all of this. While Bill was undergoing the political change, she became very quiet and moved away from the national spotlight. I assure you, however, that she is still around. At the recent National Prayer Breakfast she was heard to say, "I have to confess that it has crossed my mind that you could not be a Republican and a Christian (at the same time)."

You might be right about my dislike for lawyers mixing with medicine. Even our Supreme Court is hearing an argument about allowing physicians to participate in assisted suicide. Forget about the morality, or even the 
general propriety of it all. What I worry about is that once the lawyers get a hold of it physicians will now be sued if the patient lives.

From what I hear from your neighbourhood the Rt Hon Tony Blair has come down with a terrible case of the "Clinton's". Now this political business is either really infectious, indicating a serious medical problem, or there have been some voluntary conversions. Leo and Hazel's son went to Oxford, just like Bill. And he was "called to the bar" just like Bill (language from Mr Blair's homepage on the net alluding to events probably announced by angels). He went so far as to find a lovely lawyer wife. I hope that Cherie will leave the business of government and medicine to her husband.

\section{Too many doctors?}

Here I am, mired in middle age up to my armpits trying to give you sage interpretations on the doings in American politics/medicine and today we are hit with another incredible announcement. The Medicare folks at Health Care Fincancing Administration (HCFA, you can call it "hick-vah" along with us Yanks) announced they were beginning a programme to pay hospitals to not train physicians. It's all to start with 40 some hospitals in New York State this July. Too many doctors are taking too much money is the clear reasoning. The target is $25 \%$ reduction in three years.

I've become somewhat of an economic expert of late. Although my nascent businessman son in London tells me I have a lot to learn, I figure the friendly managers at HCFA have forgotten about basic Keynesian economics. Maybe they were confused after talking to the good folks at the US Department of Agriculture. The USDA people have been using the "pay to not play" scheme since the days of FDR back in the 1930s. Too much wheat, too many chickens and turkeys was no problem. The USDA would simply pay the farmers to not produce wheat, corn or turkeys until the prices went up. Basic supply and demand.
Let's see, cut down the number of physicians and medical costs will fall, they probably reasoned. Maybe the financial haemorrhage will stop. If he could speak from the grave, I am sure that John Maynard Keynes would be laughing at this bit of economic naïvety. Hey fellows! if you limit the physicians you drive prices up. Next thing they will do is announce a programme to limit the occurrence of disease, just to make it all balance.

I know you've had it with us Americans. You always tell me that all we do is work in our tiny corner of the world, ignoring everybody else and then imposing our styles and judgments on others. Please recognise that several political commentators have already remarked that this new programme will destine generations of physicians to senior training positions for inappropriate numbers of years, rendering them incapable of caring for patients in an independent health economy. I wonder if they ever heard the word registrar? I don't know if your phenomena are transmittable across oceans, but do you feel like you're getting even? I'm going out to buy several of those nice blue shirts with starched white collars and cuffs to give to every young physician preparing for the future.

Lest you think I only have a taste for raillery, I do believe that this is all working in some way for the good. These strange events should cause us all to think about our primary mission of patient care and how best to achieve it. The politics on any side of any ocean affects us all. Our nations may lose their identity before this is all over, but the patients will never lose theirs.

That's how it goes from here. The dollar is up against the Yen and the Deutschmark, our stock market is at an all time high, Star Wars is back, and I finally have a date with a surgeon in an operating room.

Sincerely,

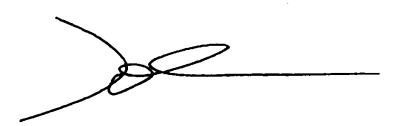

